\title{
Hammarskjöld and apartheid South Africa: Mission unaccomplished
}

\author{
Tor Sellström ${ }^{\star}$
}

\section{Abstract}

With regard to Africa, the latter part of Dag Hammarskjöld's tenure as Secretary-General of the United Nations (UN) (April 1953-September 1961) was dominated by the process of decolonisation and the Congo war. His active involvement, leadership and personal sacrifices in favour of national self-determination and peace are here well documented. Less known is that Hammarskjöld also was requested by the UN Security Council to seek ways and means to uphold the principles of the UN Charter and to safeguard human rights in the Union of South Africa. To this end, he visited the country between 6 and 12 January 1961, holding six meetings with Prime Minister Hendrik Verwoerd. After the visit, he reported to the Security Council that 'no mutually acceptable arrangement' had been found, adding that he wished to once again pursue the matter at an appropriate time (Hammarskjöld 1961). The Congo war and Hammarskjöld's death in Northern Rhodesia (Zambia) would put an end to this ambition. Introduced by comments on Hammarskjöld, the UN and Africa, and with the addendum 'mission unaccomplished', this article discusses some aspects of the Secretary-General's brief stay in apartheid South Africa in January 1961.

* Tor Sellström is a researcher with the Nordic Africa Institute (NAI) in Uppsala, Sweden. $\mathrm{He}$ is the author of Sweden and national liberation in Southern Africa, a three-volume study published by NAI in 1999/2002. Between 2006 and 2010, he served as senior advisor to ACCORD in Durban. In January 2011, Sellström was awarded the degree of doctor honoris causa by the University of Uppsala. 


\section{Hammarskjöld, Africa and decolonisation}

One of Hammarskjöld's biographers, the Swedish diplomat Kaj Falkman, has described how Hammarskjöld at an early stage, both as a humanist and an economist, took an interest in African affairs, strongly believing that the UN would become 'the engine for the new African states' development to modern societies' (Falkman 2005:42). As a humanist, he was in this regard inter alia influenced by Albert Schweitzer, the Franco-German theologian, philosopher and medical missionary, founder of the Albert Schweitzer Hospital in Lambaréné (Gabon) and recipient of the 1952 Nobel Peace Prize, with whom Hammarskjöld maintained a rich correspondence. As an economist, ${ }^{1}$ he was instrumental in the planning for a UN Economic Commission for Africa (UNECA), which following a decision by the General Assembly was established in Addis Ababa in 1958. In 1958, he also took a firm stand in favour of African self-determination. When Guinea (Conakry) rejected the plans of French President de Gaulle for continued association with France within a larger Francophone Community - opting instead for full independence -, Paris struck back. Overnight, French civil servants were ordered to leave and economic and technical cooperation was brought to a halt. In this situation, and to the French President's great vexation, Secretary-General Hammarskjöld sent a UN representative to Conakry to mobilise and coordinate international support for the newly independent state. ${ }^{2}$

The year 1960 - symbolically declared 'Africa Year' by the UN - was particularly eventful with regard to the UN's and Hammarskjöld's involvement with Africa.

1 Hammarskjöld held a Ph.D. degree in economics from the University of Stockholm, where, in 1933, he became Assistant Professor of Political Economics. In 1936, he was appointed Permanent Under-Secretary in the Swedish Ministry of Finance, at the same time serving as Chairman of the Board of Governors of the Bank of Sweden. In 1947, he moved to the Ministry for Foreign Affairs, where he was actively involved in the launch of the Marshall Plan and in the post-Second World War reconstruction of Europe.

2 The French president never forgave Hammarskjöld's act of defiance. In addition to different positions on Algeria and the Congo, a rift opened between the two. During a visit to New York in 1960, for example, de Gaulle rejected an invitation to meet Hammarskjöld, stating that since the General Assembly was not in session 'How would I [then] be able to meet [the UN]?' See Guéhenno 2005:185. 
In the beginning of the year ${ }^{3}$ the Secretary-General went on a whirlwind factfinding mission to no less than 21 countries and territories on the continent, assessing their needs and shaping his vision for international cooperation. He later said that the trip made him 'both wiser and more humble, as well as less prone to generalize, since the [countries] had many different problems, attitudes and traditions' (Falkman 2005:42). In general, however, he was impressed by the African leaders and their quest for socio-economic development.

By 1960, it was becoming evident that the world was changing and that the decolonising territories would soon be ascendant in the UN General Assembly. During the year, no less than 17 newly independent states - 16 of them from Africa - joined the UN, and in December the General Assembly adopted the seminal 'Declaration on the Granting of Independence to Colonial Countries and Peoples', a watershed in the history of colonialism. A draft resolution on decolonisation had been introduced by the Soviet Union - represented in New York by its Premier, Nikita Khrushchev - during stormy assembly proceedings in September/October 1960. ${ }^{4}$ Popularly known as the 'Decolonisation Declaration', the final Resolution 1514 of 14 December 1960 established that:

- ' $[\mathrm{t}]$ he subjection of peoples to alien subjugation, domination and exploitation constitutes a denial of fundamental human rights, is contrary to the Charter of the United Nations and is an impediment to the promotion of world peace and cooperation'; and that

3 Hammarskjöld's African tour took place from 18 December 1959 to 31 January 1960.

4 As vividly described by the Soviet leader's son and biographer, Sergei Khrushchev, the 1960 UN General Assembly meeting - the last under Secretary-General Hammarskjöld - was marked by a series of extraordinary events. Among them was the famous 'shoe incident', where the Soviet Premier punctuated an intervention during the decolonisation debate by waving a shoe. (The shoe had been lost during Khrushchev's tumultuous entry into the assembly hall. Subsequently found by a UN orderly and placed on his desk, Khrushchev instinctively picked it up during the debate). Of greater significance was Khrushchev's defeated proposal during the debate on the Congo to replace the UN Secretary-General with a 'troika' of representatives from the Socialist, Western and Non-aligned camps and to move the UN headquarters from New York to West Berlin or Geneva. See Khrushchev 2005:64-74. 


\section{Tor Sellström}

- '[a]ll peoples have the right to self-determination; by virtue of that right they freely determine their political status and freely pursue their economic, social and cultural development' (United Nations 1960:49). ${ }^{5}$

Also in 1960, however, developments in the formally independent Union of South Africa and in the then recently born Republic of the Congo were to sharply illustrate the complexities of the African peoples' march towards freedom and national self-determination. On 21 March 1960, the apartheid police killed 69 people and wounded another 180 peacefully demonstrating against the racial pass laws in Sharpeville, South Africa. And four months later - on 14 July 1960 -, in the wake of its independence on 30 June and in a rapid vortex of military mutinies, popular revolts, Belgian intervention and secession by the Katanga province, the Security Council decided to dispatch UN troops to the Congo to restore order and keep peace. As with the struggle against apartheid, this, however, was to be a bloody and drawn out process during which SecretaryGeneral Hammarskjöld on 18 September 1961 was to pay the ultimate price.

\section{Sharpeville and the UN Security Council}

In response to the Sharpeville massacre, the UN Security Council on 1 April adopted Resolution 134(1960).6 Initiated by 29 African and Asian member states, it established that 'the situation in the Union of South Africa ... has led to international friction and, if continued, might endanger peace and security'. Deploring the loss of life, as well as the policies and actions of the Pretoria government, the Security Council requested the UN Secretary-General 'in consultation with the government of the Union of South Africa, to make such arrangements as would adequately help in upholding the purposes and principles of the [UN] Charter and to report [back] whenever necessary and appropriate'

5 Resolution 1514 (1960) was adopted by 89 votes to 0, with 9 abstentions. Among the countries that abstained were Belgium, France, Portugal, South Africa, United Kingdom and the United States.

6 On the UN and apartheid South Africa, see Reddy 2008 and Sellström 2009. 
(Security Council 1960:245). ${ }^{7}$ South Africa's permanent representative to the UN participated in the meeting, strongly arguing that the resolution violated the principle of non-interference in matters falling under domestic jurisdiction of member states.

Over the following days - while the situation rapidly deteriorated in South Africa, on 8 April culminating in the banning of the African National Congress (ANC) and the Pan-Africanist Congress (PAC) -, Hammarskjöld entered into contact with Pretoria, proposing consultations between the parties. Whereas the Secretary-General after the bloodshed at Sharpeville stated his opinion that the UN was, indeed, entitled to discuss the racial situation in South Africa, adding that ' $[\mathrm{i}] \mathrm{n}$ humanitarian terms you need not have any doubts about my feelings' (Time Magazine 1960), the South African government requested that the proposed deliberations would not 'require prior recognition from the Union government of the United Nations authority. ${ }^{8}$ Thus representing radically opposing positions, at the Commonwealth Prime Ministers' Conference in London in mid-May 1960 Hammarskjöld and the South African Foreign Minister Eric Louw nevertheless reached an agreement that the UN SecretaryGeneral should visit South Africa. ${ }^{9}$

Due to the crisis in the Congo, the visit was re-scheduled. In his interim report to the Security Council in October 1960, Hammarskjöld explained that '[d]ue to

7 In light of its future pariah status, it is ironic that South Africa was among the UN's founding nations. In June 1945, South African Prime Minister Jan Smuts played an instrumental role in the drafting of the preamble to the UN Charter, which reaffirms 'equal rights of men and women, and of nations large and small'. Domestically and with regard to South West Africa/Namibia, however, his policies were far from the spirit expressed there. In 1946, only one year later, Smuts ruthlessly suppressed a general strike by black South African mineworkers, as well as demanding Namibia's annexation to South Africa.

8 Hammarskjöld 1961, quoted in UNDPI 1994:246.

9 Hammarskjöld was careful to always act as an international civil servant. It is, however, possible that Louw's attitude towards the Secretary-General was tainted by contempt for Sweden and its stand against apartheid. In October 1960, for example, Louw stated in the UN General Assembly that 'the press of [Sweden and Norway], particularly Sweden, has with one or two exceptions been carrying on a vindictive and malicious campaign against [South Africa]. I should say that the press campaign carried on there is one of the worst of any country in the world' (Sellström 1999b: 133). 


\section{Tor Sellström}

circumstances resulting from the mandate given to me by the Security Council ... in connection with the United Nations operations in the Republic of the Congo (Léopoldville), I have been unable to visit the Union of South Africa as envisaged ... On four occasions, precise plans were made for the visit, but on each occasion it became necessary first to postpone, then to cancel those plans ....'10

Eventually - and despite acute crises in Laos, Algeria and in the relations between Cuba and the United States -, Hammarskjöld visited South Africa from 6 to 12 January 1961, formally as a guest of the Pretoria government. During the short stay, he held six meetings with Prime Minister Verwoerd and made stopovers in Pretoria, Johannesburg, Umtata and Cape Town. Originally, it was his plan to stay two more days, but due to yet another Security Council meeting over developments in the Congo, Hammarskjöld had to cut the visit short. ${ }^{11}$

\section{African concerns}

Hammarskjöld's visit to South Africa was the first ever by a UN SecretaryGeneral. As such, it created great expectations within the anti-apartheid opposition, including the then recently banned liberation movements. Although the situation in the country had been steadily worsening - inter alia illustrated by the opening of the Treason Trial in $1956^{12}$ - towards the end of the $1950 \mathrm{~s}$ the issue of apartheid had largely faded from UN attention. As noted by Enuga Reddy, the Indian national who in 1963 was appointed Principal Secretary of the UN Special Committee against Apartheid, '[t]he resolutions of the General Assembly did not reflect the grave developments in South Africa, [nor] the growing international solidarity with the struggle for freedom' (Reddy 2008:50).

10 Hammarskjöld 1961, quoted in UNDPI 1994:247.

11 Hammarskjöld 1961, quoted in UNDPI 1994:247.

12 In December 1956, 156 leaders of the ANC and allied organisations within the Congress Alliance (see below) were arrested and charged with high treason. According to the state, the anti-apartheid opposition's programmatic Freedom Charter - adopted by the Kliptown Congress of the People in 1955 - was a communist document designed to overthrow the government. After protracted proceedings, the state's case was eventually overturned by the Supreme Court and the last 30 accused - among them Nelson Mandela and Walter Sisulu - were acquitted on 29 March 1961. Thus, the Treason Trial was still in process when Hammarskjöld visited the country. 
This radically changed with the Sharpeville massacre and Security Council Resolution 134(1960), which recognised that developments in the country could endanger international peace and security.

Despite the bannings, the oppression and the squalor, at the time of the visit there was a certain degree of optimism within the South African opposition. Writing about this period in the mid-1970s, Karis and Gerhart commented: 'Looking back at early $1961 \ldots$, it is difficult to appreciate the extent to which African leaders and other radical opponents of the government felt that the trend of events was in their favour.... As South Africa entered the 1960s, morale was boosted by the emergence of black independent states on the continent and the gradual mounting of pressures against South Africa' (Karis and Carter 1977:359). In this spirit, the anti-apartheid movement made submissions to the UN Secretary-General before and during his visit to South Africa. The ANC-led Congress Alliance ${ }^{13}$ also set up a 'Dag Hammarskjoeld Welcoming Committee'.

On the initiative of the ANC, ${ }^{14}$ several African leaders met for a consultative conference in Orlando, Johannesburg, in mid-December 1960. Mainly concerned with the issue of unity between the different African political organisations, the conference also discussed the potential role of the UN and the pending visit by

13 Formed in 1953, the Congress Alliance included the African National Congress (ANC), the South African Indian Congress (SAIC), the Coloured People's Congress (CPC), the Congress of Democrats (CoD) and the South African Congress of Trade Unions (SACTU). White members of the banned South African Communist Party (SACP) were active within the CoD. In June 1955, the Congress Alliance organised the Congress of the People in Kliptown outside Johannesburg, where the Freedom Charter was adopted. It could be noted that the pro-Moscow SACP did not hold Secretary-General Hammarskjöld in high esteem. In the July 1961 issue of its publication The African Communist, it turned against 'Mr. Hammarskjold and his lieutenants, who are committed to the hilt to maintain colonialism in the Congo and elsewhere in Africa', adding: 'This time it is not merely a question of Hammarskjold going. Go he must, but clearly the whole machinery of the United Nations needs overhauling. Not surprisingly, instead the SACP underlined 'the solid merits of the proposals of N.S. Khrushch[e]v for a three-man secretariat, representing the three main groups of countries: the socialist, the imperialist and the neutralist' (SACP 1961:9).

14 Invitations to the consultative conference were sent out by Chief Albert Luthuli, PresidentGeneral of the ANC. Luthuli himself was banned to his homestead in Groutville outside Durban and could not attend. 


\section{Tor Sellström}

its Secretary-General. The final resolution, dated 17 December 1960, was sent to the UN and to Oliver Tambo, the ANC leader who after Sharpeville had left South Africa to represent the movement in exile. ${ }^{15}$ With regard to Hammarskjöld and the UN, it stated that ' $[\mathrm{t}$ ] his conference of African leaders welcomes the resolution of the Security Council ... and in particular the visit of the SecretaryGeneral, Mr Dag Hammarskjold, but urges that in order to have a true view of the situation in the country, he should meet African leaders' (Karis and Carter 1977:628). In view of the situation in Transkei, the resolution, in addition, appealed to the UN 'to send a Commission of Observers to Pondoland and to use its good offices to curb the alarming military operations against unarmed people, which constitutes a threat to peace in South Africa' (Karis and Carter 1977:627-628).

The consultative conference also sent a cable directly to Hammarskjöld in New York, in addition to the appeals that he meet with African leaders and that the UN send observers to Pondoland supporting the demand for national independence of South West Africa (Namibia). The text of the brief cable read as follows:

Conference of African leaders welcomes Security Council resolution on South Africa and proposed visit of Secretary General. Firmly urge[s] get true picture of South Africa by meeting African leaders. Pondoland situation alarming. Military operations against unarmed Africans. Recommend[s] UN send commission of observers. Support[s] demand South West African people for independence. Nationalist government no moral nor legal right to rule (Karis and Carter 1977:628).

The concerns raised by the African leaders will be discussed below. In the meantime, it could further be noted that the Congress Alliance's 'Dag Hammarskjoeld Welcoming Committee' issued a pamphlet (Dag

15 Tambo had crossed the border into Bechuanaland (Botswana) at the end of March 1960. From there, he sent a cable to the UN Secretary-General, requesting an appearance before the Security Council to explain the nature of the South African crisis. The request was not granted. Subsequently, he appeared before the UN General Assembly's Fourth (Decolonisation) Committee in connection with South West Africa/Namibia (Thomas 1996:110-111). 
Hammarskjoeld Welcoming Committee no date a) to welcome the SecretaryGeneral to the country. Headed 'Greetings Dag Hammarskjoeld', it expressed the 'fervent hope' that he would 'help to reverse the tide of racial oppression'. Noting that 'over two thousand political prisoners of all races and many others have suffered months of imprisonment without charge' since the adoption of Security Council Resolution 134 in April 1960, it called on 'Dag' to 'meet the non-white leaders', foremost the ANC President-General, Chief Albert Luthuli, and to 'insist that South Africa observe the spirit of [the] UN' by ending the state of emergency, releasing [the] detainees, abandoning apartheid and ensuring democratic rights for all. ${ }^{16}$

Finally, on the day of Hammarskjöld's arrival in the country the Congress Alliance managed with great difficulty - but also ingenuity - to forward a long memorandum to the Secretary-General. According to the final report by the Welcoming Committee, one of the leaders of the demonstration that received Hammarskjöld in Pretoria 'tried to hand him a copy of the memorandum, but he refused to accept it. Subsequently, [it] was sent in to him [at the Union Hotel] concealed in a wreath of flowers' (Dag Hammarskjoeld Welcoming Committee no date $b: 1)$.

In contrast to the resolution taken at the African leaders' conference, the memorandum by the Congress Alliance did not raise concrete, urgent concerns, but described the political and socio-economic situation of the non-white majority in vivid, but general terms. Stating that 'we are sitting on a volcano due to erupt at any time', the memorandum continued: 'An eruption in South Africa would have world-wide repercussions. Whereas the unjust nature of South Africa's form of government was only of academic interest in the past, it is now a source of great concern to many nations throughout the world. This is because South African tension and violence is recognized as a threat to world peace'.

16 This pamphlet (Dag Hammarskjoeld Welcoming Committee no date a), as well as the 'Report on the visit of the Secretary-General of the United Nations to the Union of South Africa in January 1961' (Dag Hammarskjoeld Welcoming Committee no date b), is stored in the Auden House Collection of the South African Institute of Race Relations (SAIRR) at the University of the Witwatersrand, Johannesburg. The documents were kindly made available for this article by Carol Archibald, Research Assistant at SAIRR. 


\section{Tor Sellström}

Turning to the UN Secretary-General, the Congress Alliance concluded: 'Above all, we hope that your investigations here will bear out our repeated contention that the South African government is a monster imposing its arrogant will on a dissenting people. We hope that you will recognize, as we do, that this government is holding the vast majority of our people down by sheer force and that its policies are contrary to world practice. We hope, too, that you will inform the Security Council that the majority of the South African people are looking to that body for substantial assistance in their struggles for the realization of true democracy in our country' (Congress Alliance 1961).

\section{Restrictions}

Little information has transpired from Hammarskjöld's off-the-record meetings with Verwoerd, or, in general, from his talks with the South African authorities. Reporting to the Ministry for Foreign Affairs in Stockholm, Eyvind Bratt, the Swedish envoy to the country, noted in a dispirited letter two weeks after the Secretary-General's departure that ' $[i] n$ case the ministry has expected particular information from this legation regarding the visit of Dag Hammarskjöld to South Africa, I must at the outset confess that I am incapable of producing anything of the sort', adding that no foreign diplomat had been invited by the Pretoria government to meet the UN representative (Bratt 1961). In his memoirs, the Canadian diplomat Gordon Brown similarly notes that 'the visit ... seemed to have been designed ... to exclude the local diplomats' (Gordon Brown 2000:69). From conversations held by Bratt and Gordon Brown with South African officials, documents by the Congress Alliance, contemporary press reports and indirect sources, it is, however, possible to distil the most important parts.

When the South African government accepted the visit, it had been agreed that 'while consultation throughout would be with the Union government, no restrictive rules were to be imposed on the Secretary-General. ${ }^{17}$ Although denied by Prime Minister Verwoerd (The Star 1961), the latter, however, was far from being the case. While in South Africa, Hammarskjöld's movements were severely circumscribed and any contacts with people other than government

17 Hammarskjöld 1961, quoted in UNDPI 1994:246. 
representatives highly restricted. The Congress Alliance later reported: 'Throughout the visit, the press and the public had great difficulty in obtaining information about his whereabouts and plans. Mr Hammarskjöld's party was rushed from one end of the country to the other at great speed and in great secrecy. ... During [the] stay, he has been accompanied everywhere by officials and shown only what the government could be expected to want him to see' (Dag Hammarskjoeld Welcoming Committee no date b:3-4).

That this was by design is inter alia evident from Gordon Brown's memoirs and from the way in which the Pretoria government received Hammarskjöld in the country. In a meeting with one Frikkie Botha at the South African Department of External Affairs one week before the visit, Gordon Brown quoting from his diary - was told that 'the South African government is not putting Hammarskjöld in touch with opposition leaders or non-whites other than the Coloured Advisory Council (an unpopular group with most coloureds) and Botha Sigcau, the head chief in the Transkei' (Gordon Brown 2000:69). And when Hammarskjöld on 6 January arrived from Léopoldville (Congo), the South African hosts re-directed his plane from the international airport in Johannesburg to the Waterkloof military airbase in Pretoria to avoid the big crowds that had gathered in Johannesburg. In the final event, however, many demonstrators, mostly Africans, managed to turn up outside Hammarskjöld's hotel in Pretoria, where they 'produced placards ([which] had been hidden under coats) welcoming him to the police state, asking him if he had his pass and referring to Pondoland' (Gordon Brown 2000:69).

Despite the government's efforts, similar scenes would take place throughout the visit. In Cape Town, for example, large crowds of white and non-white demonstrators broke through the security cordons in Parliament Street and outside the Mount Nelson Hotel, calling out to Hammarskjöld that he should 'Go to Pondoland!' and 'Stop seeing the government - Talk to the leaders of the people!' After the meeting with the Coloured Advisory Council that had been arranged by the government, the popular wrath was directed to the council representatives, who were denounced as 'traitors and scum' (Svenska Dagbladet 1961a). On the same occasion, George Peake - one of the original Treason Trialists, later imprisoned on Robben Island with Nelson Mandela 


\section{Tor Sellström}

- tried to present Hammarskjöld with a memorandum from the Coloured People's Congress, but was detained by the Special Branch (Dag Hammarskjoeld Welcoming Committee no date b:1).

\section{Hammarskjöld and Verwoerd}

How, then, did the discussions with Prime Minister Verwoerd go? There were, as noted, no less than six meetings between the two, in accordance with Hammarskjöld's Security Council mandate aiming at 'arrangements [that] would adequately help in upholding the purposes and principles of the [UN] Charter [in South Africa]'. As the meetings were off-the-record, there is little information available, but enough to see why the two parties from the beginning agreed to disagree. Basing himself on trusted sources, in his letter to the Swedish Foreign Ministry Eyvind Bratt (1961) noted that 'Hammarskjöld during his first encounter with Verwoerd very firmly made it clear that since the apartheid [policy] was completely unacceptable to the United Nations, any exchange of ideas in this regard was pointless'. Having shortly before declared that his government would be 'as unyielding as walls of granite' in applying apartheid, ${ }^{18}$ not surprisingly Verwoerd was equally firm in closing the door to any UN-initiated arrangement. On the first occasion thus agreeing to disagree on the very question that had brought the UN Secretary-General to South Africa, it seems that Hammarskjöld and Verwoerd during the remaining meetings discussed other issues, such as the changing political map of Africa, the Congo crisis etc. After their last meeting on 12 January 1961, the South African Department of External Affairs issued a communiqué which through its lack of content reflected the deep disagreement:

The talks between the Prime Minister and the Secretary-General of the United Nations, which commenced on 6 January, have now been concluded. These discussions were frank, constructive and helpful. The Prime Minister, while recalling that these talks did not imply recognition by the Union government of United Nations authority, took the opportunity of explaining Union policies and their application. The Secretary-General on his side elaborated his

18 Quoted in Karis and Carter 1977:360. Verwoerd's 'granite speech' was held on 30 November 1960. 
views and suggestions on questions within his mandate. The Prime Minister and the Secretary-General welcomed the exchange of views. It is the intention of the Prime Minister to inform his cabinet of the substance of the talks and after consultation with his colleagues he will make a further public statement. The Secretary-General will make a report to the Security Council (South African Information Service 1961).

In less private circumstances during the stage-managed visit, Hammarskjöld did manage to put his critical views across. Replying to a toast at a dinner in Cape Town in his honour, given by J.N. Malan, Administrator of Cape Province, the Secretary-General characterised South Africa's place in the contemporary world as 'provocative' when considering the world of tomorrow. Referring to the many new African member states of the United Nations, he said that ' $[\mathrm{s}] \mathrm{o}$ much history has been made, and you are living in a world of turmoil.... Our problem [at the $\mathrm{UN}$ ] is to find, as quickly as possible, the bridges by which these [African] peoples will be able to play their fullest part and render their contribution to the international community. I therefore see in my own way a bit of the problem you have to solve', adding that ' $\mathrm{t}$ ] he most essential feature is recognition of a common and shared problem' (Gray 1961:127).

Such views were not always diplomatically received by Hammarskjöld's South African hosts. ${ }^{19}$ To the apartheid government it was anathema to be seen as part of a community with the newly independent African states, which at the $\mathrm{UN}$ and elsewhere strongly opposed its racial policies. At another dinner in Hammarskjöld's honour, this time in Umtata during the visit to Pondoland, it was reported in the local press that Hans Abraham, Commissioner-General for Transkei, had been 'unpleasant, provoking and downright bad-mannered' towards the Secretary-General. It was further alleged that Hammarskjöld -

19 Among the South African government representatives that Hammarskjöld met were M.D.C. de Wet, Minister of Bantu Administration, P. Sauer, Minister of Public Works, D.C.H. Uys, Minister of Agricultural Economics and Marketing, and P.M.K. le Roux, Minister of Agricultural Technical Services. 


\section{Tor Sellström}

normally cool and unruffled - had lost his temper and that he 'gave Mr Abraham back better than he got from him' (Sunday Times 1961).

\section{Arranged meetings, visit to Pondoland and the question of Namibia}

Welcoming the UN Secretary-General to South Africa in mid-December 1960, the ANC-dominated consultative conference urged him to also meet African leaders and visit Pondoland. In addition, the conference conveyed its support for Namibia's independence.

Before the visit, it had been agreed between the Secretary-General and the South African Foreign Minister that 'consultation throughout would be with the Union government'. Any meeting that Hammarskjöld might request was thus subject to Pretoria's approval. This said, on the last day of his stay he saw Dr A.B. Xuma, former President-General of the ANC (1940-49), and Dr W.F. Nkomo, a former leader of the ANC Youth League. ${ }^{20}$ Selected as African spokespersons by the government, the two medical doctors had long since outlived their roles as leading representatives of the anti-apartheid movement. In his memoirs, Nelson Mandela later wrote that Xuma 'enjoyed the relationships he had formed with the white establishment and did not want to jeopardize them with political action' (Mandela 1994:92). After Sharpeville, Nkomo, similarly, had acted as a mediator vis-à-vis the government and would as a trustee of the Bantu Welfare Trust promote cooperation between black and white South Africans. This notwithstanding, the South African officials must have been dismayed when Xuma and Nkomo told Hammarskjöld that men such as the banished ANC President-General Albert Luthuli and the jailed PAC President Robert Sobukwe were regarded as 'the real leadership'. ${ }^{21}$

20 Present at the meeting was also one K.T. Masemola. Commenting on the African spokespersons, the Congress Alliance's Welcoming Committee wrote that Xuma 'was last politically active ten years ago', Nkomo 'belongs to no African political organization' and Masemola 'is completely unknown in public life' (Dag Hammarskjoeld Welcoming Committee no date b:3).

21 Callan 1962, quoted in Karis and Carter 1977:360, 378. 
Following a special request to the South African government (The New York Times 1961a), from Cape Town Hammarskjöld managed to make a detour by air to Umtata, the administrative centre of Transkei in the conflict area of Pondoland. From Umtata, he went 140 kilometres by car through Pondoland to the village of Lusikisiki, one of the main sites of the conflict. ${ }^{22}$ As noted, such a visit had been urged by both the African leaders' consultative conference in midDecember 1960 and by the demonstrators that greeted the Secretary-General in Pretoria and Cape Town.

At the time, eastern Pondoland was an area in revolt.23 After decades of oppression, in March 1960 - around the time of the massacre at Sharpeville outside Johannesburg - a vast popular uprising had been launched by the Pondo people in the rural areas around Umtata, turning against land dispossession, increasing taxation and Pretoria's imposition of so called 'Bantu authorities'. Despite the government's harsh reaction, notably using military aircraft to bombard villages, killing scores and arresting hundreds of people, the uprising did not abate. ${ }^{24}$ As 23 Pondo leaders were sentenced to death and subsequently hanged in Pretoria, ${ }^{25}$ in November 1960 the government declared a state of emergency in the area. During the following police operations, nearly 5000 people were arrested. As a consequence, 'all semblance of normal life disappeared. Cultivation ground to a halt and families were impoverished as they were forced to sell livestock so as to pay tax defaulting fines' (Lodge 1983:281).

22 On the way, Hammarskjöld passed through Flagstaff, another hot spot in the Pondo uprising.

23 The epicentre of the uprising was the Bizana district, the birthplace of Oliver Tambo and Winnie Madikizela-Mandela. Nelson Mandela grew up in Qunu, just outside Umtata.

24 In mid-1960, a Mountain Committee (known as Intaba) formed by the Pondo peasants managed to send a memorandum to the United Nations in New York, explaining the situation in the area, listing their grievances and giving a vivid description of the government's repression. It is not known if Hammarskjöld was aware of the document. Under the heading 'Pondoland goes to the United Nations', it was presented in Fighting Talk 1960.

25 During the sittings of the South African Truth and Reconciliation Commission, it was in 1997 decided to locate the bodies and bring them back for re-burial in the Transkei. After delicate excavations in Pretoria, the remains of 13 of the 23 bodies were laid to rest in Flagstaff in June 2003 (Sunday Tribune 2003). 


\section{Tor Sellström}

Hammarskjöld's visit on 9 January 1961 took place at a critical moment. It is, however, unlikely that he was in a position to gather much independent information about the developments as he not only was accompanied by De Wet Nel, Minister of Bantu Administration and largely responsible for the state of affairs, but as African interlocutors had Paramount Chief Botha Sigcau and eight other government-imposed tribal leaders. ${ }^{26}$ Chief Sigcau, in particular, was the object of popular disapproval. A couple of years earlier, a meeting attended by thousands of peasants had demanded that he should publicly declare whether he was 'the head of the Pondo tribe or the boot-licker of Verwoerd' (Mbeki 1984:119).27 And by mid-1960, they declared that '[ $t$ ] he beginnings of the trouble lie in the appointment of Botha Sigcau' (Fighting Talk 1960).

In the cable sent to Hammarskjöld in mid-December 1960, the meeting of the African leaders had, finally, expressed their support for Namibia's independence. Albeit without any concrete proposal for action, it was a timely reminder of the world body's special responsibility for the territory.

The UN had inherited supervisory authority over South West Africa from the League of Nations. The Pretoria government, however, refused to place the territory under a trusteeship agreement, demanding that it be incorporated into the Union of South Africa. In 1946, the General Assembly rejected South Africa's demands. Pretoria ignored the decision, instead tightening its control. Thus began a drawn out tug-of-war between the UN and apartheid South Africa on the status of South West Africa/Namibia.

On 18 December 1960 - less than a month before Hammarskjöld's departure for South Africa -, the General Assembly deprecated the application of apartheid by the Pretoria government in Namibia, recognised the territory's inalienable right

26 According to a report in The Star newspaper of 10 January 1961, in Umtata Hammarskjöld also met Chief Kaiser Matanzima of Tembuland. By law and custom Nelson Mandela's nephew, the two African leaders developed a serious disagreement around the Pretoria government's homeland policy. Siding with the government, in 1963 Matanzima became Chief Minister of Transkei. In 1976 - when Transkei was the first homeland to be declared independent -, he became Prime Minister and in 1979 State President.

27 The classic study South Africa: The peasants' revolt by the ANC leader Govan Mbeki was first published by Penguin Africa Library in 1964. 
to independence and stated that the situation constituted a 'serious threat to international peace and security'. At the same time, it instructed its Committee on South West Africa to visit the country to investigate 'steps which would enable the indigenous inhabitants ... to achieve a wide measure of internal self-government, designed to lead them to complete independence as soon as possible. ${ }^{28}$ Acting on behalf of the African group at the UN, Liberia and Ethiopia also instituted proceedings against South Africa before the International Court of Justice with a view to legally settle the status of the country, as well as South Africa's obligations to the UN and to the people of Namibia.

In January 1961, the question of Namibia was therefore high on the UN agenda and there was speculation in the media that Hammarskjöld during his stay in South Africa would raise it with the Pretoria government or even request a visit to Namibia (Svenska Dagbladet 1961a). No documentary evidence to that effect is, however, available. As the Secretary-General's mandate by the Security Council was limited to South Africa proper, and the General Assembly had decided to send its own special committee to the country, it is unlikely that the subject came up for discussion.

\section{African townships}

In less than a week, Hammarskjöld's visit took him to Pretoria, Cape Town, Umtata/Pondoland and via Johannesburg back to Pretoria, where he had a last meeting with Prime Minister Verwoerd at the Union Buildings. ${ }^{29}$ As noted, the visit was tightly controlled by the South African government. In Johannesburg on the day before his departure, the authorities, however, lowered their guard, for the first and only time allowing the Secretary-General to get into contact with ordinary people.

28 UN General Assembly Resolution 1568 (XV) of 18 December 1960, quoted in Katjavivi 1988:56. Eventually, the South African government refused the committee entry into Namibia, stating that any attempt by the UN to cross into the country would be regarded as an act of aggression.

29 As Hammarskjöld eight months later would lose his life in an air crash, it could be noted that the Viscount plane that the South African air force put at his disposal had to be replaced before the flight to Umtata due to a crack in one of the wings (Svenska Dagbladet 1961b). 


\section{Tor Sellström}

It is not known if Hammarskjöld during his stopover in Johannesburg had made a special request to visit racially segregated areas. In addition to a lunch offered by the Transvaal and Free State Chamber of Mines at the Blyvooruitsig gold mine, that was, however, what the programme amounted to. During the day, he toured the white suburbs of Rosebank and Parktown, followed by longer stops in the African townships of Alexandra, popularly known as 'Dark City' due to the absence of electricity, and Meadowlands, where 14000 families forcefully evicted from Sophiatown had been resettled. According to contemporary press reports, Hammarskjöld surprised his government escort by leaving his car and moving among the people: 'Mr Hammarskjold went into one of the houses and spoke with the housewife as she was busy with her chores. Hundreds of African children gathered in the street and surrounded [him] when he emerged. He shook their hands and laughed at their excited cries. Altogether, the SecretaryGeneral went into five African homes in his first informal contact with the African people [of South Africa]' (The New York Times 1961b). ${ }^{30}$

On the day of his departure, Hammarskjöld also visited the African township of Atteridgeville in Pretoria. ${ }^{31}$ Albeit briefly, before leaving the country he thus got an impression of residential apartheid and the radically different conditions of the white and black population groups, living in worlds apart. As will be seen below, soon after his return to New York he would in a personal capacity also be involved in a case where the inhumanity of apartheid struck against two people who had dared to cross the racial divide.

\section{Two reports: Hammarskjöld and the Congress Alliance}

In his report to the Security Council, Hammarskjöld explained on 23 January 1961 that 'during the discussions between the Secretary-General and the Prime Minister of the Union of South Africa, so far no mutually acceptable arrangement has been found'. He was of the opinion, however, that 'the exchange of views in general has served a most useful purpose' and that the 'lack of agreement is not conclusive'. Wishing 'to give the matter his further consideration', the

30 Also Svenska Dagbladet 1961c.

31 In Pretoria, he also held a meeting with leaders of the Dutch Reformed Church. 
Secretary-General stated that he looks forward to [the] continuation [of the consultations] at an appropriate time, with a view to further efforts from his side to find an adequate solution'. In the report, he also quoted Verwoerd, noting that the South African Premier had 'decided to invite him ... to visit the Union again in order that the present contact may be continued.' 32

The Dag Hammarskjoeld Welcoming Committee of the ANC-led Congress Alliance also produced a report from the visit. The five-page typewritten document was considerably less positive, in particular criticising the UN Secretary-General for failing to 'make any effort to meet the leaders of [the] opposition political organizations, particularly the [n] on-[w]hites' (Dag Hammarskjoeld Welcoming Committee no date b:2), and for not publicly condemning the apartheid regime. While noting that 'it should be made clear that Mr Hammarskjoeld's tour was carefully planned to avoid any places and persons whom the government did not wish him to see', the committee, nevertheless, denounced the SecretaryGeneral's UN entourage for not following up on offers made to meet the Congress leaders. ${ }^{33}$ Hammarskjöld's Africa expert, Heinrich Wieschhoff, was singled out. ${ }^{34}$ In addition, the committee stated, 'there was [during the visit] no manifestation of the disapproval which the Security Council feels about [the] Union government's policies'. Of the opinion that Hammarskjöld 'should have adopted a more correct and impersonal attitude towards the government and its supporters', it quoted statements allegedly made by the Secretary-General in favour of the Pretoria regime, adding that ' $[\mathrm{i}] \mathrm{f}$ the reported versions are correct

32 Hammarskjöld 1961, quoted in UNDPI 1994:247.

33 According to the report, offers were made by the Welcoming Committee to facilitate an interview with leaders of the Congress Alliance in Pretoria. During Hammarskjöld's stopover in Umtata, cables were also sent to him from Durban, requesting meetings with Chief Luthuli of the ANC and Dr Naicker of the Natal Indian Congress (Dag Hammarskjoeld Welcoming Committee no date b:2). In his report to the Security Council, Hammarskjöld stated that he had 'unofficial contacts with members of various sections of the South African community' (Hammarskjöld 1961, quoted in UNDPI 1994:247).

34 Wieschhoff was Director of the UN Department of Political and Security Council Affairs. Holding a Ph.D. in African anthropology, he was the author of a number of books on African cultures and on colonial policies. He died together with Hammarskjöld in the air crash at Ndola in September 1961. 


\section{Tor Sellström}

... they merit the strongest condemnation' (Dag Hammarskjoeld Welcoming Committee no date b:2, 4). ${ }^{35}$

Through its report, the Welcoming Committee relayed to the leadership of the Congress Alliance the overall opinion that 'the visit was a great disappointment', that it 'meant nothing positive for the majority of the people' and that 'there is a fear that the Security Council will not receive an objective report from Mr Hammarskjoeld' (Dag Hammarskjoeld Welcoming Committee no date $\mathrm{b}: 2,4)$. At the same time, however, it underlined that 'we do not question the motives of Mr Hammarskjoeld in the way in which his visit was carried out, ... [but express] disappointment and doubt as to the merit of the procedure adopted by the Security Council' (Dag Hammarskjoeld Welcoming Committee no date b:5). ${ }^{36}$

While the Secretary-General hardly could be seen to publicly side with the antiapartheid opposition and at the same time pursue sensitive consultations with the Pretoria government - a principle every mediator to a conflict must respect-, it is, in addition, difficult from both formal and practical points of view to see how he could have met with leading ANC representatives such as Chief Albert Luthuli, Walter Sisulu or Nelson Mandela. As noted above, a condition for Pretoria's acceptance of the visit was that 'consultation throughout would be with the Union government'. To this should be added that the ANC was outlawed, that the Treason Trial was still in process and that Luthuli, Sisulu and Mandela all were either banished, banned or underground. ${ }^{37}$

For Hammarskjöld, the brief visit in early January 1961 was, finally, only a beginning. His intention to return to South Africa in search of an arrangement

35 The South African opposition press - notably The Star and The Rand Daily Mail - was surprisingly critical of the Secretary-General, often publishing general, non-committal statements as expressions of support for the government. In a meeting with the South African Press Association, Hammarskjöld regretted that he had been quoted 'out of context' (Dag Hammarskjoeld Welcoming Committee no date b:4).

36 While rhetorically asking the question 'Did Dag meet our leaders?', after Hammarskjöld's departure the Congress Alliance convened a meeting in Newclare, Johannesburg, on 15 January 1961 (Pamphlet in the Auden House Collection).

37 None of the memoirs by, or main biographies of, the ANC leaders mention Hammarskjöld's visit to South Africa. 
to uphold the principles of the UN Charter did not, however, materialise. Returning to New York, he was immediately seized with the escalating armed conflict in the Congo, where he tragically was to lose his life eight months later. In the meantime, the Pretoria government under Prime Minister Verwoerd proceeded to consolidate apartheid, breaking away from the Commonwealth and on 31 May 1961 proclaiming the Republic of South Africa.

\section{Apartheid immorality}

Although heavily occupied with the Congo crisis, soon after his return to New York Hammarskjöld, unexpectedly, was to renew contact with South Africa. Late at night on 3 February 1961, the well-known Swedish novelist Sara Lidman was arrested by the Special Branch in her flat in Yeoville, Johannesburg, together with her friend Peter Nthite, National Organising Secretary of the ANC Youth League, a former Treason Trialist and at the time serving a five-year banning order. Subsequently charged under the Immorality Act ${ }^{38}$ - with a possible penalty of ten lashes and up to seven years' imprisonment -, the arrest of Lidman and Nthite caused a scandal in South Africa and a national uproar in Sweden. Unbeknown to those involved, behind the scenes and in a private capacity the Swedish UN Secretary-General intervened in the case.

After achieving national fame in the 1950s for her novels about life in the harsh environment of northern Sweden, Lidman was at the end of the decade 'concerned with the questions of treachery and the supposed excellence of the so called Free World' 39 To address these concerns, she decided to go to South Africa. After a short period in Zululand, in October 1960 she came to Johannesburg, where she became friends with the future Nobel laureate for literature, Nadine Gordimer, frequented the multi-racial circles around Drum

38 The South African Immorality Act of 1950 - expanding earlier legislation from 1927 prohibited sexual relations between whites and non-whites in an attempt to ensure white racial 'purity'.

39 Address by Sara Lidman, Arbetarnas Bildningsförbund (The Workers' Educational Association), Stockholm, 1 November 1996. 


\section{Tor Sellström}

magazine and entered into contact with the ANC. ${ }^{40}$ This drew the attention of the security police, who monitored her movements and eventually burst into her Yeoville flat.

The charge sheet against Lidman and Nthite stated that the couple 'wrongfully and unlawfully [had] or attempt[ed] to have unlawful carnal intercourse', or, alternatively, that they 'wrongfully and unlawfully [had] conspire[d] ... to commit or attempt to commit an immoral or indecent act'. ${ }^{41}$ As news spread of the arrest and the accusations, the reactions were intense. In Sweden, 'the tremendous commotion' 42 contributed to the sharpening of the anti-apartheid opinion, with calls for action against the Pretoria government. Cultural workers were outraged and the typographers' union in Stockholm, for example, stated that 'this incident has in a brutal way made it clear to all Swedes that there must be an end to the unparalleled terror and discrimination that the rightful indigenous inhabitants [of South Africa] are subjected to.... We appeal to [the Swedish trade union confederation] and to other Swedish mass organizations to consider actions that will contribute to forcing the South African government to stop the racial persecutions.' 43

Ten days after the arrest, Foreign Minister Louw initiated a series of meetings with the Swedish envoy, Eyvind Bratt, and on 24 February the case against Lidman was suddenly withdrawn. With one of the 'offending' parties free, the charges against Nthite were also dropped. ${ }^{4}$

Without the knowledge of Bratt, the accused or other parties directly involved, the discharge was the result of an intervention by the UN Secretary-General, who had taken an initiative behind the scenes and at the highest level. In addition to his position as the head of the United Nations, Hammarskjöld was a

40 Cf. the ANC's Indres Naidoo: 'In 1960, there was a very attractive Swedish journalist who came to Johannesburg .... Her name was Sara Lidman. We used to meet her quite often' (Interview with Naidoo, Cape Town, 7 December 1995, quoted in Sellström 1999a:175).

41 Quoted (in English) in Holm 1998:232.

42 Letter from Per Wästberg to the author, Stockholm, 9 April 1997.

43 Expressen, Stockholm, 9 February 1961, quoted in Sellström 1999a:153-154.

44 While Lidman left South Africa the following day, Nthite was re-arrested on $12 \mathrm{March}$, this time accused of illegal possession of a firearm. 
member of the prestigious Swedish Academy, ${ }^{45}$ well acquainted with the literary scene in his home country and had met Sara Lidman on several occasions. As soon as the arrest became known, Jytte Bonnier, a leading figure in Sweden's cultural life and a personal friend of both Hammarskjöld and Lidman, wrote to the Secretary-General, asking for his assistance. His reaction was swift. On 10 February 1961, he sent a cable to Bonnier, telling her: 'Have sent personal message to Prime Minister, explaining as well as possible situation and pleading for his immediate personal attention. This, of course, in no way can be given publicity as I have been able to send such message only in personal capacity, anything else being beyond my competence'. 46 And on 1 March, after the South African state's withdrawal of the case, he noted with satisfaction in another cable to Bonnier that 'I received message from Prime Minister showing his decisive personal intervention for which you carry ultimate merit.' 47

It is not known which arguments Hammarskjöld used or how Verwoerd acted against his own apartheid laws. ${ }^{48}$ For both of them, the interventions were potentially damaging. ${ }^{49}$ It is, however, fair to surmise that the personal contact established between the Secretary-General and the Prime Minister only the previous month made the denouement of the Lidman-Nthite affair possible. It

45 The Swedish Academy awards the Nobel Prize for literature. Hammarskjöld took his father's seat in the academy in 1954, the year after being appointed UN Secretary-General. It is said that he hoped to become the academy's secretary once his UN tenure was over.

46 Quoted (in English) in Holm 1998:234.

47 Quoted (in English) in Holm 1998:234.

48 It is of interest to note that the South African Afrikaans-speaking newspaper Dagbreek, a staunch supporter of the apartheid policy, without knowledge of Prime Minister Verwoerd's personal role strongly criticised Pretoria's handling of the case (Holm 1998:234).

49 Hammarskjöld's role as a member of the Swedish Academy had in 1958-59 added to the growing political discord between the Secretary-General and the Soviet Premier Nikita Khrushchev. In 1958, the Swedish Academy awarded the Nobel Prize for literature to Boris Pasternak, the Russian author of Doctor Zhivago. The decision was seen by Moscow as an expression of support for the dissident movement in the Soviet Union, and Pasternak was forced by the authorities to decline the award. The matter was raised by Khrushchev during a visit to the Soviet Union by Hammarskjöld in 1959. According to Sergei Khrushchev, ' $[\mathrm{u}]$ nder the guise of a literary discussion, the two parties engaged in an ideological dispute, and failed to see eye to eye. They parted civilly, but were not happy with each other's positions' (quoted in Ask and Jungkvist 2005:69). See also Wallensteen 2005:30-31. 


\section{Tor Sellström}

is also likely that the case weighed heavily on Hammarskjöld's opinion of South Africa's racial policies.

\section{Epilogue: Disaster and Nobel Prize}

After his visit in January 1961, Hammarskjöld never returned to South Africa. His death at Ndola in September and the posthumous Nobel Peace Prize in Oslo in December were, however, to be associated with the country and the antiapartheid struggle.

The circumstances surrounding the death of the UN Secretary-General and fifteen others in an air crash in Northern Rhodesia (Zambia) have never been convincingly established. Three different investigations were carried out to determine why the plane went down and why there was no immediate rescue operation. In the absence of forensic means to establish the facts, the disaster, however, remains an unresolved mystery. While the simplest explanation - a navigational error - appears to be the most reasonable (Wallensteen 2005:37), numerous theories have over the years been presented. One of them suggests that white mercenaries hired by Western intelligence agencies and fighting for Katanga's secession from the Congo were behind the crash. It gained new currency in August 1998, when Archbishop Desmond Tutu, Chairman of the South African Truth and Reconciliation Commission, presented documents discovered during the course of the commission's work. According to the documents, the fatal air crash could have been the result of sabotage against Hammarskjöld's plane, coordinated by US, British and South African secret services (Svenska Dagbladet 1998).

One month after Hammarskjöld's death, it was announced by the Norwegian Nobel Committee that Chief Albert Luthuli, President-General of the outlawed ANC of South Africa, had been awarded the Peace Prize for 1960.50 It was the first time that the coveted prize was given to an African. At the same time, the

50 During the selection process in 1960, the Nobel Committee concluded that none of the nominations met the criteria as outlined in the will of Alfred Nobel. In such a case, the prize can be reserved until the following year. In 1961, Luthuli therefore received the Peace Prize for 1960. 
prize for 1961 was posthumously awarded to Dag Hammarskjöld. It was the first time that a posthumous award was made. Although the two champions for global peace, freedom and justice, as well as for self-determination, unity and development in Africa, did not personally meet in South Africa earlier in the year, in Norway in December 1961 their visions combined to inspire millions the world over. ${ }^{51}$ While the Nobel Committee emphasised that the two laureates 'fought for the ideals expressed in the declaration of human rights embodied in the Charter of the United Nations' (Gunnar 2004:15), in his Nobel lecture on 11 December 1961 Chief Luthuli, simply, described Hammarskjöld as a 'fighter for peace' (Luthuli 2004:32).

In his acceptance speech the previous day, the African laureate had portrayed Hammarskjöld as 'the devoted Chief Executive of the world'. Commenting on the role played by the late Secretary-General, Luthuli (1962) stated:

It is significant that it was in Africa, my home continent, that he gave his life. How many times his decisions helped to avert a world catastrophe will never be known. But there are many of such occasions, I am sure. [T] here can be no doubt that he steered the United Nations through one of the most difficult phases in its history. His absence from our midst today should be an enduring lesson for all peace-lovers, and a challenge to the nations of the world to eliminate those conditions in Africa, nay, anywhere, which brought about the tragic and untimely end to his life.

51 In Norway and Sweden, subsequently the leading Western countries in support of the ANC, the awards to Luthuli and Hammarskjöld played a prominent part in the development of broadly based anti-apartheid movements. 


\section{Sources}

Ask, Sten and Anna Mark-Jungkvist eds. 2005. The adventure of peace: Dag Hammarskjöld and the future of the UN. Basingstoke, Palgrave Macmillan.

Asmal, Kader, David Chidester and Wilmot James eds. 2004. South Africa's Nobel laureates: Peace, Literature and Science. Johannesburg and Cape Town, Jonathan Ball Publishers.

Bratt, Eyvind 1961. Hammarskjölds besök i Sydafrika (Hammarskjöld's visit to South Africa). Letter from Eyvind Bratt, Swedish legation, to the Ministry for Foreign Affairs in Stockholm. Cape Town, 24 January 1961.

Callan, Edward 1962. Albert John Luthuli and the South African race conflict. Kalamazoo, Western Michigan Press.

Congress Alliance 1961. Memorandum submitted to the United Nations SecretaryGeneral, Dag Hammarskjold, during his visit to South Africa (6 January 1961). Available from: <http://www.anc.org.za $>$

Dag Hammarskjoeld Welcoming Committee no date a. Greetings Dag Hammarskjoeld - Welcome to South Africa. No place of publication. Published by the Congress Alliance (see footnote 16).

Dag Hammarskjoeld Welcoming Committee no date b. Report on the visit of the Secretary-General of the United Nations to the Union of South Africa in January 1961. No place of publication. Published by the Congress Alliance (see footnote 16).

Falkman, Kaj ed. 2005. Att Föra Världens Talan: Tal och Uttalanden av Dag Hammarskjöld ('Speaking on behalf of the world: Speeches and statements by Dag Hammarskjöld'). Stockholm, Atlantis.

Fighting Talk 1960. Pondoland goes to the United Nations. Fighting Talk, 14 (5), Johannesburg.

Gordon Brown, J.C. 2000. Blazes along a diplomatic trail. Victoria, Trafford Publishing.

Gray, Alan 1961. Quarterly chronicle. African Affairs, No. 239, April.

Guéhenno, Jean-Marie 2005. The Peacekeeper. In: Ask and Mark-Jungkvist 2005, pp. 180-191.

Gunnar, Jahn 2004. Nobel Presentation. In: Asmal et al. 2004.

Hammarskjöld, Dag 1961. Report of Secretary-General Dag Hammarskjöld on certain steps taken in regard to the implementation of Security Council resolution 134(1960) including his visit to South Africa (S/4635 of 23 January 1961). In: UNDPI 1994:246-247. 


\section{Hammarskjöld and apartheid South Africa: Mission unaccomplished}

Holm, Birgitta 1998. Sara Lidman: I Liv och Text (Sara Lidman: In life and text). Stockholm, Albert Bonniers Förlag.

Karis, Thomas and Gwendolen M. Carter eds. 1977. From protest to challenge: A documentary history of African politics in South Africa 1882-1964. Volume 3: Challenge and Violence 1953-1964 (Thomas Karis and Gail M. Gerhart eds.). Stanford, Hoover Institution Press.

Katjavivi, Peter 1988. A history of resistance in Namibia. Paris and London, Unesco Press and James Currey.

Khrushchev, Sergei 2005. Nikita Khrushchev and Dag Hammarskjöld. In: Ask and Mark-Jungkvist 2005. pp. 64-74.

Lodge, Tom 1983. Black politics in South Africa since 1945. London and New York, Longman.

Luthuli, Albert 1962. Acceptance speech. Available from: <http://nobelprize.org/ nobel_prizes/peace/laureates/1960/lutuli-acceptance.html> [Accessed 15 March 2011].

Luthuli, Albert 2004. Nobel Lecture. In: Asmal et al 2004.

Mandela, Nelson 1994. Long walk to freedom. Randburg, Macdonald Purnell.

Mbeki, Govan 1984. South Africa: The peasants' revolt. London, International Defence and Aid Fund.

Reddy, Enuga S. 2008. The United Nations and the struggle for liberation in South Africa. In: South African Democracy Education Trust (SADET) The road to democracy in South Africa. Volume 3: International Solidarity, Part 1. Johannesburg, Unisa Press. pp. 41-139.

SACP (South African Communist Party) 1961. The African communist. June.

Security Council 1960. Security Council resolution: Question relating to the situation in the Union of South Africa (S/RES/134(1960) of 1 April 1960). In: UNDPI 1994:245.

Sellström, Tor ed. 1999a. Liberation in Southern Africa: Regional and Swedish voices. Uppsala, Nordiska Afrikainstitutet.

Sellström, Tor 1999b. Sweden and national liberation in Southern Africa; Volume 1: Formation of a Popular Opinion 1950-1970. Uppsala, Nordiska Afrikainstitutet.

Sellström, Tor 2009. The Trusteeship Council: Decolonisation and liberation. In: Adebajo, Adekeye ed. From global apartheid to global village: Africa and the United Nations. Scottsville, University of KwaZulu-Natal Press. pp. 107-137.

South African Information Service 1961. Communiqué by the Department of External Affairs, Pretoria, 12 January 1961. 


\section{Tor Sellström}

Sunday Times 1961. Political commentary. Sunday Times, 29 January. Johannesburg.

Sunday Tribune 2003. Pondoland rebels' remains brought home. Sunday Tribune, 8 June. Durban.

Svenska Dagbladet 1961a. Försök att 'isolera' FN-chefen i Sydafrika (Attempts to 'isolate' the UN chief in South Africa). Svenska Dagbladet, 9 January. Stockholm.

Svenska Dagbladet 1961b. Hammarskjöld till oroshärd (Hammarskjöld to trouble spot). Svenska Dagbladet, 10 January. Stockholm.

Svenska Dagbladet 1961c. Hammarskjöld hos Afrikaner i Sydafrika (Hammarskjöld with Africans in South Africa). Svenska Dagbladet, 12 January. Stockholm.

Svenska Dagbladet 1998. Svenska Dagbladet, 20 August. Stockholm.

The New York Times 1961a. UN chief in Pondoland: Hammarskjold sees Africans in restive tribal area. The New York Times, 10 January. New York.

The New York Times 1961b. UN chief visits homes. The New York Times, 12 January. New York.

The Star 1961. No obstacles for him. The Star, 9 January. Johannesburg.

Thomas, Scott 1966. The diplomacy of liberation: The foreign relations of the African National Congress since 1960. London, Tauris Academic Studies.

Time Magazine 1960. South Africa: The Sharpeville Massacre. Time Magazine, 4 April.

UNDPI (United Nations Department of Public Information) 1994. The United Nations and Apartheid, 1948-1994. New York, UNDPI.

United Nations 1960. Yearbook of the United Nations: 1960. New York, Office of Public Information.

Wallensteen, Peter 2005. Dag Hammarskjöld. Malmö, The Swedish Institute. 